\title{
Myanmar Experience with Serum IGF-1, Salmon Calcitonin and Postmenopausal Osteoporosis
}

\author{
Hein Latt Win Fics, Hta Kyi Sunn, Theingi Myint and Myo Win M.Phil
}

\begin{abstract}
A great deal of information has been obtained on the system of growth hormone and IGF-1 in development of osteoporosis. The imbalance of this system may be the cause of diseases of neonatal period as well as disease associated with aging. In old age, the synthesis of IGF - 1 declines as well as the action of this peptide on tissues. The aim of this study is to find out the association between serum IGF-1 levels and bone mineral density. Sixty postmenopausal non osteoporotic women and sixty postmenopausal osteoporotic women were selected for this study. Out of 60 cases, 50 postmenopausal osteoporotic women completed the study. Bone mineral density (BMD) of postmenopausal women with symptom of osteoporosis was measured by ultrasonic bone densitometry (UBIS5000).Postmenopausal women with BMD results of $T$ score $\leq-2.5$ were selected as cases and that of $>-1$ were selected as controls. Serum IGF -1 level was measured by ELISA method after removal of IGFBP from IGF - 1. In this study, both base line BMD and serum IGF-1 level of the osteoporotic women were significantly lower than that of non osteoporotic women $(p<0.05)$. BMD and serum IGF-1 level in 3 months after calcitonin injection of osteoporotic women were significantly higher $(p<0.001)$ than that of baseline BMD and serum IGF-1 level. There was positive correlation between baseline serum IGF-1 and BMD level in postmenopausal osteoporotic women $(r=0.470, p=0.001)$ as well as in control $(r=0.288, p=0.025)$. It is hoped that this study will serve as ground for further study in the related fields, and thus, as part for the development of applications in the management of postmenopausal osteoporotic women.
\end{abstract}

Index Terms-Calcitonin, IGF-1, Osteoporosis.

\section{INTRODUCTION}

Insulin like growth factor- 1 (IGF- 1) plays an important role in the regulation of somatic cell growth, metabolism, cell proliferation and differentiation [9]. Most IGF-1(> 80\%) circulates in a form of a high affinity complex $(150 \mathrm{kDa})$, which also contains IGFBP -3 and an acid- labile subunit (ALS).The incorporation of IGFs into this complex may

\footnotetext{
Manuscript received May 30.

HEIN LATT WIN FICS is with department of orthopaedics, wuhan union hospital, tongji medical college, huazhong university of science and technology wuhan, china, 430020.

Email: heinlattwin@gmail.com

HTA KYI SUNN is with molecular biology laboratory (li lab), tongji medical college, huazhong university of science and technology wuhan, china, 430020.Email: hksunn@gmail.com

THEINGI MYINT is with department of biochemistry, university of medicine(mandalay),mandalay,myanmar,11162.Email:theingi.myint334@ gmail.com

MYO WIN M.Phil is with department of bichemistry, university of medicine-1,yangon, myanmar, 11162.Email: dept.is.biochem@gmail.com

Correspondent should be sent to Dr Hta Kyi Sunn,Emailhksunn@gmail.com
}

limit their effects on metabolism[14]. It is essential for longitudinal bone growth[8], as it stimulates proliferation and differentiation of chondrocytes in the epiphyseal plate [5], play a role in trabecular and cortical bone formation, stimulate both proliferation and differentiation of osteoblasts, increases type I collagen synthesis, alkaline phosphatase activity and osteocalcin production[23] . IGF1 can exert anabolic effects on bone mass not only during growth, but also during adulthood [2].

IGF-1 is the principal regulator of linear growth. In the skeleton, GH stimulates osteoblast and chondrocyte production of IGF-1[5]. Serum concentrations of IGF- 1 reflect GH secretion to an indicator of GH status. Although GH represents the principal hormonal regulator of circulating IGF- 1, other determinants affect IGF-1 concentrations both in the serum and in tissue. The nutrient status of an individual can profoundly affect serum IGF1[22].Protein caloric malnutrition limits IGF-1 synthesis in the liver and leads to a $50 \%$ reduction in circulating concentrations even among healthy volunteers. Not only does serum concentration of IGF-1 decline dramatically, but the bioactivity of IGF-1 is also markedly reduced by malnutrition. There is evidence that zinc deficiency can inhibit IGF-1 synthesis in liver and bone [7]. Serum IGF concentration also vary with age, sex, pubertal stage and physiological condition and ethnicity [12].Advanced age is associated with a progressive decrease in serum IGF-1 because GH secretion declines $14 \%$ per decade of life[26].This decrement in IGF-1 is attributable to increased somatostatinergic tone and a generalized reduction in the pulses of $\mathrm{GH}$ releasing hormones and $\mathrm{GH}$ releasing peptides. Declining sex steroid production may also negatively impact the GH / IGF-1 axis [15].

\section{AIM}

The aim of this study is to find out the association between serum IGF-1 levels and bone mineral density, before and after injecting calcitonin to post menopausal osteoporotic women.

\section{MATERIALS AND METHODS}

Sixty postmenopausal osteoporotic women (age $\geq 50$ years) who visited the outpatient Department of the Orthopaedics Hospital with a low BMD (T score $\leq-2.5)$ and treated with calcitonin injections were enrolled as cases. Sixty postmenopausal non osteoporotic women (age $\geq 50$ years) with a normal BMD (T score $>-1$ ) were enrolled as 
control. Inclusion criteria for postmenopausal women was age greater than or equal to 50 years. Cases with coronary artery disease, diabetes mellitus, hypothyroidism, and other endocrine disorders, liver disease, on estrogen therapy, suspected malignancy and patients with fresh fractures or healing fractures were excluded from this study.

Recombinant human IGF-1, recombinant human IGF-2, anti human IGF-1 (goat), peroxidase conjugated antigoat (rabbit) and O- phenylenediamine dihydrochloride (OPD $5 \mathrm{mg}$ ) were used from Sigma, Japan. Salmon calcitonin (calcinin) 50IU from Nastech Company, India was used as subcutaneous injection per day for 5 days continuously.

This Quasi - experimental study was carried out from December 2006 to December 2009. BMD measurement of Calcaneus was done at first visit. For cases, BMD measurement was repeated 3 months after treatment. Determination of serum IGF- 1 concentration was done by Enzyme Linked Immunosorbent assay. Acid ethanol extraction method was used to remove IGFBP from IGF-1 and excess IGF -2 was added to bind with binding protein.

\section{Statistical Analysis}

Results were recorded in the pro forma and data were analyzed by Minitab ${ }^{\circledR} 14$ statistical software. The variables were presented as mean and standard deviation. Student $t$ test (paired and unpaired) were applied to test the significance difference between means on $95 \%$ confidence interval. Evaluation was done at the probability level of $<$ 0.05 . Pearson coefficient of correlation (r) was calculated.

\section{RESULT}

The postmenopausal osteoporotic study group of sixty women and the non osteoporotic control group of sixty women volunteered to participate in this study. The osteoporotic study group of women was treated with calcitonin injection. Two women from the osteoporotic study group quitted due to allergic reaction and gastrointestinal disturbance within 5 days of treatment with calcitonin. Seven women from the osteoporotic study group abstained from follow up after 3 months of treatment. One woman from the osteoporotic study group expired with other disease prior to follow up. Therefore out of 60 cases only 50 postmenopausal osteoporotic women completed the study.

TABLE1. Demographic Data of OSTEOPOROTIC WOMEN AND NON OSTEOPOROTIC WOMEN

\begin{tabular}{|l|l|ll|l|}
\hline Data & $\begin{array}{l}\text { Control }(\mathrm{n}= \\
60) \\
(\text { mean } \pm \text { SD) }\end{array}$ & $\begin{array}{l}\text { Case (n = } \\
50) \\
(\text { mean } \pm \\
\text { SD) }\end{array}$ & $\begin{array}{l}\text { Level of } \\
\text { significance } \\
(\mathrm{p})\end{array}$ \\
\hline Age (year) & $58.06 \pm 5.90$ & $\begin{array}{l}66.40 \quad \pm \\
7.88\end{array}$ & $<0.001^{*}$ \\
\hline $\begin{array}{l}\text { Menopausal } \\
\text { age (year) }\end{array}$ & $48 \pm 2.46$ & $\begin{array}{l}47.82 \\
2.02\end{array}$ & 0.679 \\
\hline $\begin{array}{l}\text { Year after } \\
\text { menopause } \\
\text { (year) }\end{array}$ & $10.06 \pm 5.54$ & 18.58 & \pm & $<0.001^{*}$ \\
\hline
\end{tabular}

\footnotetext{
*significance
}

Table 2 demonstrated the baseline serum IGF-1 level and baseline BMD level of osteoporotic women and non osteoporotic women. Both base line BMD and serum IGF-1 level of the osteoporotic women were significantly lower than that of non osteoporotic women $(\mathrm{p}<0.05)$.

TABLE2. BASELINE BMD AND SERUM IGF-1 LEVEL OF OSTEOPOROTIC WOMEN AND NON OSTEOPOROTIC WOMEN

\begin{tabular}{|l|l|l|l|}
\hline & $\begin{array}{l}\text { Control }(\mathrm{n}=60) \\
(\text { mean } \pm \text { SD) }\end{array}$ & $\begin{array}{l}\text { Case } \\
(\mathrm{n}=50) \\
(\text { mean } \pm \text { SD) }\end{array}$ & $\begin{array}{l}\text { Level of } \\
\text { significance(p) }\end{array}$ \\
\hline $\begin{array}{l}\text { BMD(T } \\
\text { score) }\end{array}$ & $-0.56 \pm 0.92$ & $\begin{array}{l}-3.18 \quad \pm \\
0.61\end{array}$ & $<0.05^{*}$ \\
\hline $\begin{array}{l}\text { IGF-1 } \\
(\mathrm{ng} / \mathrm{ml})\end{array}$ & $365.15 \pm 23.55$ & $\begin{array}{l}211.24 \quad \pm \\
36.30\end{array}$ & $<0.05^{*}$ \\
\hline
\end{tabular}

*significance

Serum IGF-1 level of fifty postmenopausal osteoporotic women were assigned to three groups, group 1 (baseline), group 2 (5 days after calcitonin treatment), group 3(3 months after calcitonin treatment). Serum IGF-1 levels of baseline, 5 days after treatment and 3 months after treatment were $211.24 \pm 36.30 \mathrm{ng} / \mathrm{ml}, 289.46 \pm 42.97 \mathrm{ng} / \mathrm{ml}$ and $301.42 \pm 45.22 \mathrm{ng} / \mathrm{ml}\left(\mathrm{p}<0.001^{*}\right)$. Analysis with one way ANOVA indicated a statistically significant difference between the groups $\left(\mathrm{F}_{2.147}=69.09, \mathrm{p}<0.001^{*}\right)$.

TABLE 3. BASELINE AND 3 MONTHS BMD AND SERUM IGF-1 LEVEL OF OSTEOPOROTIC WOMEN

\begin{tabular}{|l|l|l|l|}
\hline & Baseline & 3 months & P value \\
\hline BMD & $-3.18 \quad \pm$ & $-2.47 \quad \pm$ & $<0.001^{*}$ \\
(T score) & 0.61 & 0.59 & \\
(mean \pm & & & \\
SD) & & & \\
\hline Serum & 211.24 & 301.42 & $<0.001^{*}$ \\
IGF-1 & \pm 36.30 & \pm 45.22 & \\
$($ ng / ml) & & & \\
(mean \pm & & & \\
SD) & & & \\
\hline
\end{tabular}

*significance

There was also significant correlation between BMD (T score) of baseline $(-3.18 \pm 0.61)$ and 3 months after treatment in cases $(-2.47 \pm 0.59)(\mathrm{p}<0.001 *)$ (Table 3$)$.

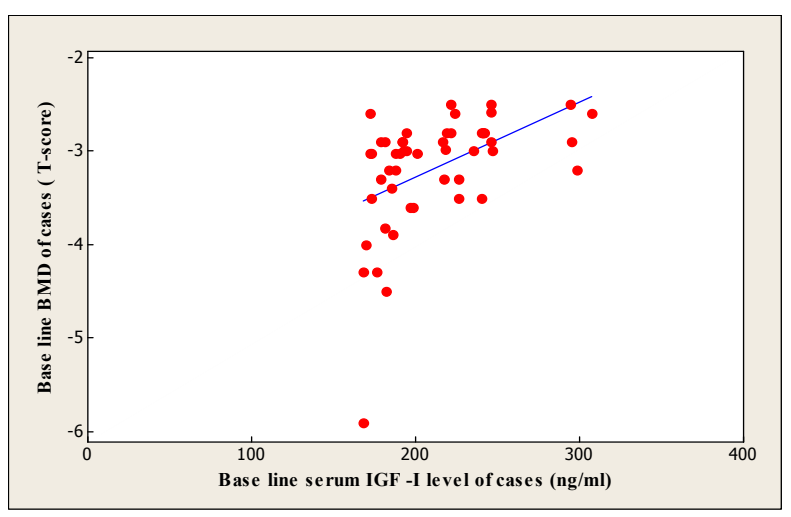

Figure 1. Correlation between baseline serum IGF-1 and BMD level in cases

There was positive correlation between baseline serum IGF-1 and BMD level in postmenopausal osteoporotic women $(\mathrm{r}=0.470, \mathrm{p}=0.001)$ (figure 1$)$ as well as in control $(\mathrm{r}=0.288, \mathrm{p}=0.025)$. 


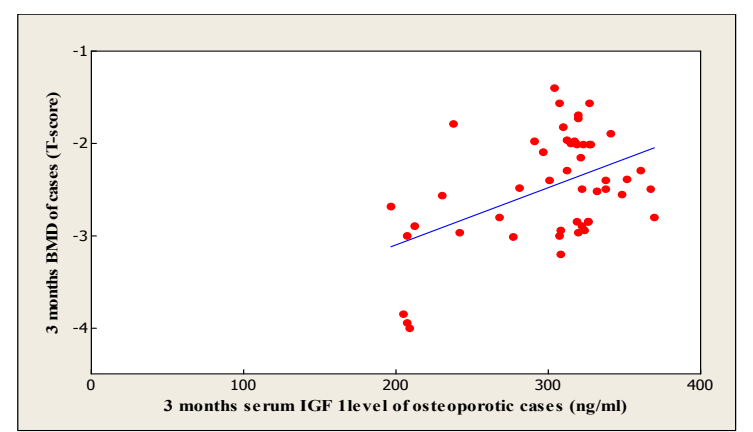

Figure 2. Correlation between serum IGF-1 level and BMD of oeoporotic cases in 3 months after calcitonin injection

The positive correlation was seen between BMD and serum IGF-1 level of 3 months after treatment with calcitonin in postmenopausal osteoporotic women $(\mathrm{r}=$ $0.471, \mathrm{p}=0.001$ ) (figure 2).

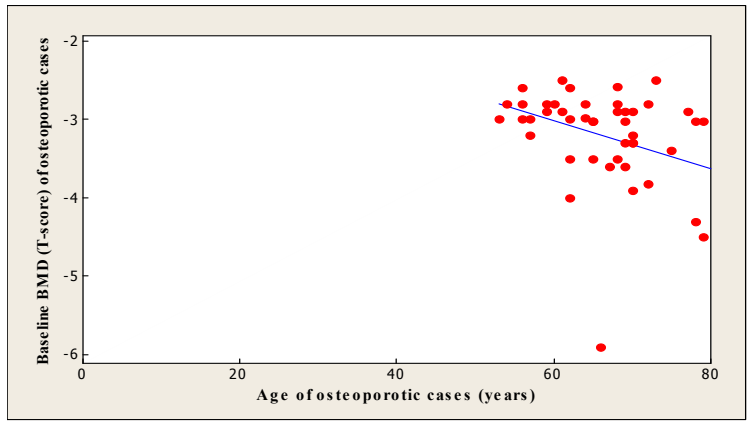

Figure 3. Correlation between age and baseline BMD of osteoporotic cases

There was negative correlation between age and baseline BMD in cases $(\mathrm{r}=-0.358, \mathrm{p}=0.011)$ (figure 3 ) as well as in control $(r=-0.321, p=0.012)$.

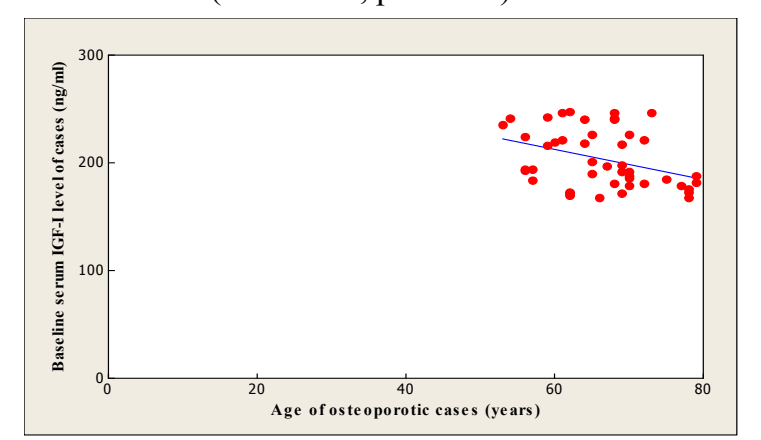

Figure 4. Correlation between age and baseline serum IGF- 1 level of osteoporotic cases

Moreover negative correlation was seen between age and baseline serum IGF-1 level in cases $(r=-0.378, p=0.007)$ (figure 4) as well as in control ( $\mathrm{r}=-0.321, \mathrm{p}=0.012)$. So, serum IGF-1 levels were reduced with advanced age.

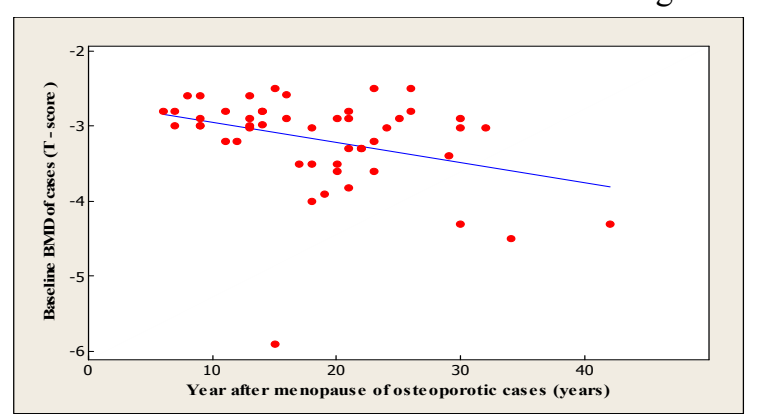

Figure 5. Correlation between year after menopause and baseline BMD of osteoporotic cases

There was negative correlation between year after menopause and baseline BMD of osteoporotic cases $(\mathrm{r}=-0.342, \mathrm{p}=0.015)$ seen in figure 5 .

But, there was no correlation between year after menopause and BMD of control $(r=-0.258, p=0.047)$.

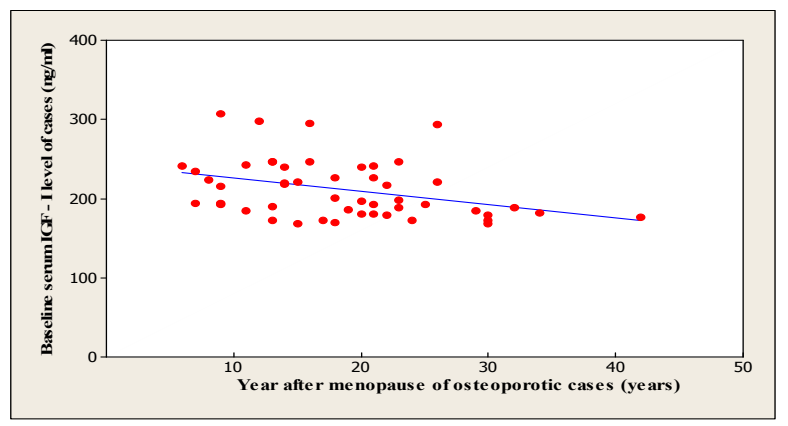

Figure 6.Correlation between year after menopause and baseline serum IGF-1 level of osteoporotic cases

As shown in figure 6, year after menopause of osteoporotic cases and baseline serum IGF -1 level were negatively correlated $(\mathrm{r}=-0.365, \mathrm{p}=0.009)$.

Similar weak negative correlation was also seen between year after menopause of control and serum IGF -1 level of control $(\mathrm{r}=-0.258, \mathrm{p}=0.047)$. So, the earlier the time of menopause, the more decrease in serum IGF-1 level and more susceptible to develop osteoporosis.

\section{DISCUSSION}

BMD values of postmenopausal osteoporotic women in this study were consistent with that of other countries[19,25].BMD values of postmenopausal osteoporotic women were in the range between $\mathrm{T}$ score of 2 and -3 . It may probably be due to a similar disease process of osteoporosis among women of this particular age in all races.BMD levels of osteoporotic women was the same in negative value, but high or low intake of dietary calcium made little significance.

In this study, BMD is reduced in osteoporotic women than non osteoporotic women. Genetic and environmental factors interact and synchronize function to get maximum level of $\mathrm{BMD}[21]$. In osteoporotic women, these functions are deteriorated and then reduce BMD. Estrogen deficiency can cause loss of bone through the direct action of estrogen on bone cells, which are involved in restraining bone turnover, and through the loss of action of estrogen on the tissue and kidney, which maintain extra skeletal calcium fluxes. Estrogen deficiency allows the production of factors that stimulate the osteoclastogenesis such as interleukin (IL). It may also inhibit osteoprotegerin (OPG), which is soluble decoy receptor for RANKL. Estrogen deficiency, by these mechanisms can lead to osteoclastogenesis, reduced life span of osteoblasts and osteocytes[16].

In the present study, the mean serum IGF-1 level of postmenopausal osteoporotic women was significantly lower than that of postmenopausal non osteoporotic women. It may be due to the decline in IGF-1 level after menopause which corresponds to the decrease in growth hormone level that occurs after menopause. Growth hormone regulates the production of IGF-1 in bone[3]. The serum IGF-1 level of osteoporotic women was compatible with that of various investigators $[6,11,18]$.

In the present study, baseline serum IGF -1 level was 
significantly correlated with baseline BMD of osteoporotic women $(r=0.470, p=0.001)$ as well as baseline BMD of non osteoporotic women $(r=0.346, p=0.006)$. It is in agreement with the finding of various investigators $[4,6,17]$.It can be suggested that in postmenopausal osteoporotic women, osteoblast cell levels are reduced after aging and production of $\mathrm{GH}$ and also IGF -1 from osteoblast cells are reduced. Moreover, estrogen level is reduced after menopause and subsequently absorption of calcium from gut is also reduced, which leads to a reduction in BMD[26] .

In the present study, age was significantly correlated with baseline serum IGF -1 level of postmenopausal osteoporotic women $(\mathrm{r}=-0.378, \mathrm{p}=0.007)$ as well as non osteoporotic women $(r=-0.321, p=0.012)$. It may be suggested that after aging, the osteoblast cells are reduced and IGF- 1 level is also reduced as it is synthesized from osteoblasts[4].

In the present study, age was negatively correlated with baseline BMD of osteoporotic women $(\mathrm{r}=-0.358, \mathrm{p}=$ 0.011 ) as well as baseline BMD of non osteoporotic women $(\mathrm{r}=-0.175, \mathrm{p}=0.178)$. This may be due to decline in estrogen level after menopause which contribute to increased bone loss. Estrogen deficiency increases extracellular calcium level and consequently suppresses renal calcium reabsorption and calcium absorption from gut via effects on PTH and calcitriol. Calcium is a substrate for bone mineralization as well as a central component of bone health. This may be due to increased resistance to action of vitamin $\mathrm{D}$ in the gut. Estrogen deficiency may impair calcium absorption directly or via decreased vitamin D production.

In the present study, duration of menopause was also negatively correlated with baseline serum IGF -1 level of osteoporotic women $(\mathrm{r}=-0.365, \mathrm{p}=0.009)$ as well as non osteoporotic women $(r=-0.258, p=0.047)$. It may be due to effect of estrogen level on production of IGF -1 because estrogen level decline progressively after menopause.

In the present study, significant negative correlation was found between year after menopause and baseline BMD of osteoporotic women $(r=-0.342, p=0.015)$. It is similar to the finding of previous investigator[4]. It is suggested that menopause is a transition from estrogen repletion to estrogen deficiency. The median age at menopause is 51 years. This transition is marked by rapid bone loss, reduced fracture risk and reduced BMD. The longer the duration of menopause, the greater the loss of BMD in osteoporotic women was seen in present study.

Serum IGF-1 level was increased 3 months after calcitonin injection in postmenopausal osteoporotic women. Before menopause there is a rise in estrogen level which inhibits the production of IL-6[10] . Following menopause the effect is vice visa[24].Calcitonin reduces the production of cytokine[1,20]and then serum IGF -1 level was negatively correlated with IL- 6[13] .

\section{CONCLUSIONS}

Calcitonin inhibits production of cytokines which negates the inhibitory effect on IGF - 1 resulting in an increase in IGF-1 production from osteoblasts. Therefore bone resorption is reduced and BMD is increased following calcitonin treatment in postmenopausal osteoporotic women.

\section{REFERENCES}

[1] Ali G, Aziz D, Remzi C, Kemal N, Mehmet K and Aysegul JS (2003). The effect of alendronate and calcitonin on cytokines in postmenopausal osteoporosis: A 6 month randomized and controlled study. Yonsei Medical Journal. 44, 1: 99 - 109.

[2] Ammann P, Rizzoli R, Meyer JM and Bonjiour JP (1996). Bone density and shape as determinants of bone strength in IGF-1 and / or palindronate treated ovariectomized rates. Osteoporosis International. 6: $219-227$.

[3] Baker J, Liu JP, Robertson E and Efstratiadis A (1993). Role of insulin like growth factors in embryonic and postnatal growth. Cell. 75: 73 - 82.

[4] Barrett CE and Goodman GD (1998). Gender differences in insulin like growth factor and bone mineral density association in old age: The Rancho Bernardo study. Journal of Bone and Mineral Research. 13: 1343 - 1349 .

[5] Canalis E, McCarthy TL and Centrella M (1991). Growth Factors and cytokines in bone cell metabolism. Annual Review of Medicine. 42: $17-24$.

[6] Ceilker R and Arslan S (2000). Comparison of serum insulin like growth factor-1 and growth hormone levels in osteoporotic and non osteoporotic postmenopausal women. Rheumatology International. 19, 6: $205-208$.

[7] Estivarez CE and Ziegler TR (1997). Nutrition and the IGF system. Endocrine. 1: $65-71$.

[8] Froesch ER, Schmid C, Schwonder J and Zapf J (1985). Actions of insulin like growth factors. Annual Review of Physiology. 47: $443-$ 467.

[9] Frystyk J, Skjaerback C, Dinesen B and Orskov H (1996). Free insulin like growth factors- 1 and 2 in human serum. FEBS Lett. 348: $185-191$.

[10] Gunsah S, Candan O, Selda B, Ozlem BC and Canan E (2002). Correlation of serum cytokine levels with axial mineral density. Singapore Medical Journal. 43, 11; 576 - 578.

[11] Heald A, Peter L S, Anne Wand Gibson JM (2000). Progestin abrogates estrogen induced changes in the insulin like growth factor axis. American Journal of Obstetrics and Gynecology .183, 3; 593 606.

[12] Hall CM, Gill MS, Foster P, Pennels L, Till M and Jones J (1999). Relationship between serum and urinary insulin like growth factor- I through childhood and adolescence: their use in the assessment of disordered growth. Clinical Endocrinology. 50: 611 - 618 .

[13] Helena FE, Lars AM, Elisabeth N and Hans C (2003). Hormone replacement therapy in rheumatoid arthritis is associated with lower serum levels of soluble IL-6 receptor and higher insulin like growth factor-1. Arthritis Research and Therapy. 5, 4: 202-209.

[14] Hill RA and Pell JM (1998). Regulation of insulin like growth factor bioactivity in vivo: further characterization of an IGF-1 enhancing antibody. Endocrinology. 139: 1278 - 1287.

[15] Ho KY, Evans WS, Blizzard R, Veldhuis JD, Merriam G and Amojlik KE (1987). Effects of sex and age on the 24 hour profiles of growth hormone secretion and importance of endogenous estradiol concentrations. Journal of Clinical Endocrinology and Metabolism. 64: 51-58.

[16] Hofbauer LC and Schoppet M (2000). Clinical implication of the osteoprotegerin/ RANKL/RANK system for bone ans vascular disease. JAMA. 292:490-495.

[17] Janssen JA, Burger H, Stolk RP, Grobbee DE, de Jong FH, Lanberts SW and Pols HA (1998). Gender specific relationship between serum free and total IGF-1 and bone mineral density in elderly men and women. European Journal of Endocrinology. 138: 627 - 632.

[18] Jung GK, Kyong RR and Jin YL (2002). The relationship among serum insulin like growth factor-1, insulin like growth factor-1 gene polymorphism, and bone mineral density in postmenopausal women in Korea. American Journal of Obstetrics and Gynecology. 186: 345 -350 .

[19] Masi L, Lucia B, Emanuela C, Luigi G, Riccardo M, Alberto F, Angela MB, Chiara C, Stefano G, Annalisa T and Marina LB (1998). Polymorphisms of the calcitonin receptor gene are associated with bone mineral density in postmenopausal women. Biochemical and Biophysical Research Communication. 248: 190-195.

[20] Ozoran K, Seckin U, Tutkak H and Mermerci B (2005). Calcitonin therapy in postmenopausal osteoporosis: effects on serum levels of interleukin-1, interleukin- 6 and tumor necrosis factor $-\alpha$. Journal of Rheumatology. 8, 1: 39-42.

[21] Rizzolli R, Ammann P, Bourrin S, Chevalley T and Bonjour JP (2001). Protein intake and bone homeostasis. In Nutritional aspect of osteoporosis, pp 219-235. 
[22] Rosen CJ and Conover C (1997). Growth insulin like growth factor-I axis in aging: a summary of an NIA sponsored symposium. Journal of Clinical Endocrinology and Metabolism. 82: 3919-3922.

[23] Schmid C and Ernst M (1992). Insulin like growth factors. In Cytokines and Bone Metabolism, pp 229 - 265. Ed M Gowen, Bone Raton, Ann Arboe, London: CRC Press.

[24] Steven LT (2004). Postmenopausal osteoporosis, T cells, and immune dysfunction. PNAS. 101, 48: 16711 - 16712.

[25] Taboulet J, Frenkian M, Frendo JL, Feingold N, Jullienne A and de Vernejoul MC (1998). Calcium receptor polymorphism is associated with a decreased fracture risk in postmenopausal women. Human Molecular Genetics. 7, 13: 2129 -2133.

[26] Veldhuis JD, Iranmanesh A and Weltman A (1997). Elements in the patho physiology of diminished $\mathrm{GH}$ secretion in aging humans. Endocrine. 7: $41-48$.

[27] Wallace LS and Ballard JE (2004). Lifetime physical activity and calcium intake related to bone density in young women. Journal of Women Health and Genetic based Medicine. $11389-11398$.
Hein Latt Win Fics, biography and photograph not available at the time of publishing.

Hta Kyi Sunn, biography and photograph not available at the time of publishing.

Theingi Myint, biography and photograph not available at the time of publishing.

Myo Win M.Phil, biography and photograph not available at the time of publishing. 